\title{
Research on Student Management Model of Higher Vocational Colleges Based on Cloud Platform
}

\author{
Xu Yang ${ }^{1, a}$ \\ ${ }^{1}$ Tianjin Bohai Vocational Technical College, 300402, Tianjin, P.R. China
}

\begin{abstract}
This paper analyzes the current situation of higher vocational students and the problems existing in the management of higher vocational students, and puts forward the idea of making use of cloud computing technology to innovate the management of higher vocational students, that is, to construct an interactive system based on the educational cloud platform. To realize the interaction between teachers and students. The construction of student management model based on cloud platform is the requirement of information construction of student management and the reform of talent training mode in higher vocational colleges.
\end{abstract}

\section{The connotation of student management in higher vocational colleges}

Student management is a general term for planning, organizing, coordinating and controlling students' learning and activities outside school. It is the process that the school administrator organizes and guides the students to carry out various kinds of education according to the educational standard, aim, plan and organization, so as to promote the students' all-round development and accomplish the task of training professional talents more effectively.

The management of students in higher vocational colleges is an important part of school management, which includes the daily management of students, the ideological and political education of students, the cultivation of good behavior of students and so on. The level of student management is directly related to the normal operation of the school teaching order, and plays an important role in the realization of the goal of talent cultivation in vocational colleges and in promoting the growth of students. On the one hand, compared with ordinary colleges and universities, the quality of students in higher vocational colleges is poor. Students' knowledge base, learning ability, learning habits, learning attitude and enthusiasm have a big gap compared with ordinary colleges and universities. On the other hand, the goal of talents training in higher vocational colleges is quite high. The decision of the State Council on speeding up the Development of Modern Vocational Education (Guofa [2014] 19) clearly points out that vocational education should train hundreds of millions of highquality workers and technical and skilled personnel.

\section{Overview of the educational cloud platform}

\subsection{Basic definition of educational cloud platform}

The educational cloud is the first professional education platform to apply cloud computing technology to the field of education. Cloud computing assisted education is a new subject which intersects computer and education. It mainly uses its own powerful computing power to assist all kinds of education, teaching activities, exploring the application law of fusion with mainstream learning theory. It provides powerful resource sharing for education and teaching, and design and management of all kinds of teaching. The whole quality education cloud platform structure is mainly realized with cloud computing as the framework, centralized hosting and providing platform, resources sharing and abandoning the isolated island of information, taking the school education community as the existing education network, and upgrading the campus network for the non-website. Schools provide a new generation of education network, campus network, class network. The education cloud platform realizes the Internet, telecommunication network, radio and television network cross-platform use and mobile short message support for Unicom, telecommunications, mobile network coverage.

\subsection{Basic functions of educational cloud platform}

The educational cloud platform offers many useful features, such as cloud-based collaboration and interaction, online forums, online documentation, 
Wikiblog, and so on. Under the guidance of counselors and teachers, under the environment of educational cloud platform, students can independently cooperate to create columns such as class resources, class dynamics, class announcements, class photo albums, class compositions and class competitions, etc.. Using these columns to carry out related activities can effectively narrow the distance between class students and teachers, students and students, and further enhance the cohesion of the class.

Education blogs facilitate students to learn, discuss, communicate and progress with each other; they also allow students to fully demonstrate their personality and express their views in blogs or Weibo so that their parents can pay attention to their children's growth at any time. And cultivate the student has the thought, is good at and dares to express the ability, promotes the student to grow healthily.

\section{The connotation of student management model in higher vocational colleges based on cloud platform}

Management is a system engineering, the essence of management is service. With higher vocational colleges hardware conditions continue to improve, transformation of cultivating mode in the development of education information and talents, the traditional mode of thinking and mode of student management has a serious impact on the students management in higher vocational colleges, the overall level of service, hindered the process of information construction and application of higher vocational colleges the level of student management mode in higher vocational colleges. Based on cloud platform is based on cloud network platform, with the help of information technology, through multiple parallel collaborative work management system, student management departments, for students to provide convenient, efficient service, real time for students, working mode, comprehensive management type. The construction of the model takes the student perspective as the starting point, deconstructs the existing work pattern divided by the student management department, and then according to the common and individual characteristics of the various work tasks, takes the business process as the main line.

\section{The significance of implementing student management model based on cloud platform in higher vocational colleges}

\subsection{The important contents of the Construction of Educational Informatization in higher Vocational Colleges}

The Ministry of Education's "Education Informatization Development Plan 2011-2020" points out that education informatization should be placed in the strategic position of supporting and leading the modernization of education.
Accelerating the construction of vocational education informatization has gradually become the consensus of vocational colleges and universities. A few days ago, driven by the tide of educational informatization, the informational education and teaching reform in higher vocational colleges, like the development of fire and tea, changed the traditional learning model, broke the restrictions of time and space, and met the needs and autonomy of students. Flexible learning requirements, meet the needs of ubiquitous learning, teaching efficiency and teaching quality has been greatly improved. Higher vocational college student management as an important part of school education and teaching, compared with the application of information technology in education and teaching management, there is still a big gap in the level of informatization construction of student management in leaving colleges and universities, although some information products have been used.

\subsection{The need of Educational and Teaching Reform in higher Vocational Colleges}

At present, the higher occupation education in our country is to expand the size change of epitaxial objective mode for development to enhance the quality of the core connotation type development model. In order to adapt to this change, higher vocational colleges by insisting on open education, deepening cooperation, such as modern apprentice system, such as the alternation of the combination of talent training mode came into being, enrich the content of school enterprise cooperation, deepen the reform of higher occupation education, has injected new vitality into the occupation education. Selection and orientation of talent training mode, breaking the administrative class construction in Higher Vocational Colleges of the traditional teaching mode and learning mode, which requires the internal organization management in higher vocational colleges, The flexible teaching and learning mode also brings new challenges to the management of students in higher vocational colleges.

\section{The strategy of constructing student management model based on cloud platform in higher vocational colleges}

\subsection{Strengthen the consciousness of Service and change the way of work}

Service is the essence of student management. Since the late 1990s, the connotation of student work in colleges and universities has changed greatly. Besides emphasizing the functions of education and management, the functions of guiding and serving students have been emphasized. The concept of student affairs management, such as "student-oriented" and "one-stop service", has gradually formed. The two basic contents of "student service" and "student development" have become the main connotations of student affairs.

Built to serve as the main working mode of the student management work platform, must put down the 
focus of the work, in-depth understanding of the status of the students as the starting point, to promote the all-round development of students as the ultimate goal of the work, highlight the dominant position of students, understand students seeking reasonable litigation. At the same time, the use of management platform for students to give full play to students' self management ability and strengthen students' autonomous management. We must make it clear that the transformation of student management work, is not a simple leap, not reinvent the wheel, but with improved inheritance.

\subsection{Integrate work tasks and build management platform}

The construction of student management platform is the practical environment and important foundation of constructing student management model based on cloud platform in higher vocational colleges. The traditional student management mode has low information level, or each management system is relatively independent, and the efficiency of student management work is low, which can not better reflect the basic purpose of student service. According to the practice of student management in higher vocational colleges under the background of educational information construction, a student management platform based on cloud platform is built to ensure the systematization, comprehensiveness and immediacy of student management, and to improve the quality of service to students.

\subsection{Optimize management team and improve service capability}

The student management team in higher vocational colleges is mainly centered on the student work department, the admissions and employment department, the League committee, the security department and the student work office of the departments, including counselors, class teachers, professional teachers, etc.. Jointly carry out ideological and political education to students, daily management education work. There are many problems in traditional student management, such as single way, long working cycle, disordered procedure, low efficiency and so on. The student management model based on cloud platform is implemented with the help of open network platform, which has the characteristics of strong comprehensiveness, timeliness and standardization. To build a team with outstanding ability is to ensure higher vocational education. A key content of the efficient operation of the student management model based on the cloud platform.

\subsection{Innovating the working Mechanism and improving the efficiency of Management}

The construction and operation of student management mode based on cloud platform has changed the traditional student management mode. The student management model of higher vocational colleges based on cloud platform requires innovative management mechanism, communication mechanism, cooperation mechanism, docking mechanism and incentive mechanism to meet the needs of the whole student management and service work. To continuously promote the healthy development of student management.

\section{Conclusion}

To sum up, there are still many problems in the management of students in higher vocational colleges, which brings great challenges to the management of students in higher vocational colleges. In view of this, students' managers in higher vocational colleges should apply modern information technology to student management, which can not only help students build up their confidence in learning, but also do a good job of student management.

Educational informatization is a means, not an end. The construction of student management model based on cloud platform through information technology is the requirement of higher vocational college student management information construction, which has strong practicality and popularization value. Due to the late start of information construction in higher vocational colleges, there are still many deficiencies in the practice of this model, which need to be constantly explored and perfected.

\section{References}

1. Cao Yang. Study on the difficulties and Countermeasures of strengthening Student Management in higher Vocational Colleges [J]. Journal of Beijing Labor and Security Vocational College.

2. Dai Haiqun, Tao Wei. A probe into the work of Class Teachers in higher Vocational Colleges [J]. Science and Technology Information Development and economy.

3. Chen Zhibin. Discussion on Student work in higher Vocational Colleges [J]. China Adult Education (2009 / 23).

4. Luo Zheng. A brief talk on the present situation and Countermeasures of Student Management in higher Vocational Colleges [J]. Journal of Tianjin Institute of Finance and Trade Management. 